\title{
Trading Influence as the Phenomenon of the Corruption in Indonesia (Study of application of UNCAC principles of trading influence in corruption act law in Indonesia)
}

\author{
Mokhammad Najih \\ University of Muhammadiyah \\ Malang \\ najih@umm.ac.id
}

\author{
Fifik Wiryani \\ University of Muhammadiyah \\ Malang \\ fwiryani2016@gmail.com
}

\author{
Kenny Desinta Saraswanti \\ University of Muhammadiyah \\ Malang \\ kennydesinta@gmail.com
}

\begin{abstract}
This study intends to describe the model of engaging in the influence of corruption in Indonesia. Although it has not been regulated in anti-corruption laws, some cases of trafficking have been prosecuted by applying the provisions of a bribery offense. Reviewing the application of the principles of trading the influence of UNCAC on corruption courts in Indonesia is very important, in order to help people understands about law enforcement and the application of new principles in the courts and in efforts to renew the penal law, including to know some of its weaknesses and advantages. This research uses normative juridical approach method, with primary and secondary law material source, with some cases of corruption which have been reach a verdict in court, then analyzed by content analysis technique. The results of the research shows that elements of trading influence have been applied in law enforcement to cases of criminal acts of corruption. It can be found there are two models in the case of trading influence, namely vertical model and horizontal model. Therefore, to be more effective in punishing those who trade influence, it is necessary to immediately reform the corruption law, by accepting the principles of trade in influence as referred to in UNCAC as a crime.
\end{abstract}

Keywords: Trading in Influence, UNCAC, Corruption

\section{INTRODUCTION}

With legalization of Law No. 7 of 2006 on the Ratification of the United Nations Convention Against Corruption (UNCAC), adopted on 18 December 2003, Indonesia has legally become a State responsible for implementing the principles of anti-corruption in the
Convention. Therefore, to meet the requirements for member states that have ratified UNCAC, member countries need to arrange in more detail the prevention and eradication of corruption in their country in accordance with the applicable provisions. One of the highlights in the UNCAC provisions is the provisions set forth in Article 18 letters (a) and (b) on trading in influence.

Trading in influence is provided for in Article 18 (a) and (b) of UNCAC. The provision reads: Each State Party may consider taking such legislative and other measures as may be necessary to establish a criminal offense, if committed intentionally:

1. Promise, offering or giving to any public official or other person, directly or indirectly, an improper benefit to a public official or person misusing its actual or perceived influence with the intention of obtaining from a public official an undue advantage for the true instigating interest of such action or for anyone else;

2. The solicitation or acceptance by any public official or other person, directly or indirectly, of undue benefit to himself or to others so that the public official or the person abuses his or her real or perceived influence with the intention of obtaining from a public official a benefit which is not appropriate

The elements contained in the article are:

The form of error in the article is deliberate as the intent meaning that the offender wants the deed and its consequences.

The subject of the criminal law of the article shall not only be a public official, but also any person, whether or not having a relationship with that public official. It can be argued that in the formulation of the article there is an extension of criminal liability to the perpetrator who trades influence. 
By the term "undue advantage," UNCAC covers a wide range of promised or offered incentives to public officials or others.

A very easy distinction between trading in influence and bribery or gratification of a civil servant or an organizer of a State is a legal subject accepting a bribe or gratification. In bribery or gratification, the recipient's legal subject must be a civil servant or a State administrator.

The case of Lutfi Hasan Ishaq, as has been decided with the decision of the criminal case number 38 / PID.SUS / TPK / 2013 / PN.JKT.PST, PKS party president and member of the House of Representatives, has influenced the minister Suswono to increase the quota of imported meat. Where Suswono is also a PKS party cadre. If this case is applied, the bribery article will not be fulfilled by the elements [1].

In connection with Lutfi Hasan Ishaq's position, the judges of the Jakarta Corruption Court in his consideration cited the decision of Hoge Raad on 26 June 1916 which essentially stated:

It is not necessary that the civil servant or official be authorized to perform the services requested thereof, but sufficiently that the position is possible. Moreover, "relating to position" is not necessarily based on laws or administrative provisions. Thus, the Defendant to provide his services to Maria Elizabeth Liman, it is not necessary to have the authority to issue recommendation on the addition of import quota of beef, but it is enough that the position of defendant as member of DPR-RI from PKS party as well as PKS Party President makes it possible to do so, in case for the Minister of Agriculture which has authority to issue a recommendation to add the import quota of beef to witness Maria Elizabeth Liman (PT.Indoguna Utama), because the Minister of Agriculture at that time was held by PKS party cadres Suswono, while the Defendant was a member of DPR-RI from the PKS party as well as the PKS Party President. "

The basis of judges' consideration in the decision of Lutfi Hassan Ishaaq (LHI) as mentioned above, there is no judge's consideration that LHI's act of receiving money from Fatanah which is money from Maria Elizabeth Liman is related to the position or position of LHI. The judge decides that it is not necessary that the person receiving the bribe really has the authority. If the basis of the judge's consideration is a possible position, then LHI ability to do so is his position as president of PKS not as a Member of DPR-RI Commission I (Intelligence, Defense of Security and Foreign Affairs) because the minister of agriculture is a cadre of PKS. If so, then the act of LHI as president of PKS cannot be blamed according to Article 12 Sub-Article a Corruption Act.

The connection between the acceptance of bribery and the position as meant in Article 12 Sub-Article a Corruption Act can be referred to Adhami Chazawi [2] opinion which:

The recipient's element of error, contained in the knowledge and reasonably suspect of the bribe's intention to move it to do or not to do in his position contrary to his obligations. In this case, in addition to the knowledge and reasonably expecting, the recipient's consciousness that he does have the ability to do or not to do something in his position that is contrary to his obligations, as the briber means is necessary (though not necessarily proven) is a written / written element but as an implied element only. It is impossible to establish knowledge or reasonably suspect about such intent, if objectively one does not possess such ability because his / her position is not a person who holds the position in question.

Whereas, it is clear that what has been done by LHI has fulfilled the qualification of trading element of influence (Trading in influence). So the verdict is reaping criticism from Bagir Manan who declared the verdict Lutfi Hasan Ishaq not accurate [3]. If the LHI's deed meets the qualification of the deeds of the influence trade, then what Ahmad Fathanah does is an act of influence trade as well. As can be seen from the actions agreed Ahmad Fathanah to bring Maria Elizabeth Liman with LHI as a person who has influence. Such deeds fulfill the formulation of the influence trade with the intermediary pattern or broker.

Based on the background as the author has described above. So the authors try to lift it in a form of research study with the title, "The phenomenon of Trading in Influence in Criminal Acts of Corruption in Indonesia (Study of Implementation of UNCAC Principles in Corruption Act in Indonesia)"

\section{RESEARCH ISSUES}

From the description of the above background, it can be identified several problems that are then formulated as follows: Are the Trade in Influence Principles in UNCAC been applied by the judge in the case selected in this study?

\section{RESEARCH METHODS}

The type of research used is normative legal research in order to find the rule of law, legal principles, and legal doctrines to answer the legal issues faced. Normative legal research is conducted to find problem solving on existing legal issues. The result of this study is to provide prescriptions of what should be the formulation of the 
proposed problem. The approach used is statute approach, conceptual approach, and case approach.

\section{Model Trading in Influence}

Trade influence is a form of trilateral relationship in corruption. This means that the modus operandi involves three parties, two actors from the policy making side, including those who sell their influence (not necessarily public officials/state officials) and one actor who gives something to benefit from public officials or state officials. Theoretically there are two patterns in Trading in Influence [4]:

1. Vertical Model of Trading in Influence

a) The model of trading in influence with vertical model, occurs mostly because of certain political or institutional transactions with influential people.

b) In the vertical influence trade model, the influential party is the party who has the power / authority.

c) The influence it has is used to provide incentives to individuals or groups

2. Horizontal Trading in Influence Model

a) In the horizontal effect trading model, the clients or stakeholders with the brokers are the two active parties, while the authority of public officials is the affected party.

b) The Client handed over the money to an influential party who is not a state administrator.

c) If the client directly handed money to the authority of public officials, it can be directly snared with the article of bribery.

d) This horizontal effect trading model is prevalent in the scope of political parties that have networks to executive power. People who are in government structures in taking policy are often influenced by external factors, especially those from their own political parties [4]

Lutfi Hasan Ihaq, Case Study of Trading in Influence in Indonesia

In Indonesia the case of trading in influence actually has happened many times with different modes and has occurred since long. The case ranging from cattle import quota, "papa asks for stock", to the quota of sugar imports. However, the criminalization of trading in influence until now has not existed. This legal vacuum makes law enforcers doubtful of which chapter should be prosecuted. Based on cases that have occurred, law enforcers often wear bribes for trading in influence cases.

In this research, we take the case of import quota of beef involving Luthfi Hasan Ishaq former member of House of Representatives Commission I who handles the field of Intelligence, Defense and Foreign Affairs and has been found guilty for trying to influence the Minister of Agriculture Suswono as a state official.

Based on the 38 / PID.SUS / TPK / 2013 / PN.JKT.PST corruption ruling by Luthfi Hassan Ishaq in the form of a Briber as the article charged against him, Article 12 of the
Law on the Eradication of Corruption. According to the indictment, the defendant, who is also the President of the Prosperous Justice Party (PKS), has received Rp1 billion from PT. Indoguna Utama which is one of the largest cattle importers in Indonesia.

The money is given in return for Lutfi Hassan Ishaq as the MCC President to influence or ask Suswono (Minister of Agriculture) who is his subordinate in the PKS Party to be able to increase the quota of beef imports for PT. Indoguna Utama. The action according to the judges of the Corruption Court up to the Supreme Court level examining and adjudicating, the case of Luthfi Hasan Ishaq is included in the qualification of bribery and the judges granted the appeal from the Public Prosecutor with the verdict. $1195 \mathrm{~K}$ / Pid.Sus / 2014 [1] as follows:

a) To declare Lutfi Hasan Ishaq proven legally and convincingly guilty of committing a criminal act of corruption and money laundering done jointly.

b) Punish Luthi Hasan Ishaq with imprisonment for 18 (eighteen) years and a fine of $\mathrm{Rp} 1,000,000,000.00$ (one billion rupiah) provided that if the fine is not paid is replaced with imprisonment for 6 (six) months.

c) Determined to revoke the right of LHI to be elected in public office.

Lutfi Hasan's case is a trading offense in influence. The prosecutor's indictment contains the phrase "affect". The phrase "influence" within the scope of trading in influence with ties to corruption, because it is closely related to the trading of influence with the powers that be in corruption. Relations nature of trading in influence with corruption mutual interdependence of the nature of the corruption that transformed the nature of trading in influence as a trigger corruption. The main point of trading in influence is the value of influence. Should be the center of the problem that provides the gap point of abuse based on influence, should be given greater emphasis / attention. Legal facts that occurred in the case of LHI has conformity with trading in influence with Horizontal model.

\section{RECOMMENDATIONS}

Trading in influence has not been regulated in the Corruption Act 1999 and 2001, but with the enactment of Law No. 7 of 2006 on the Ratification of the United Nations Convention against Corruption, 2003, Indonesia actually has a legal basis to punish offenders of trading in influence. Therefore, these principles can be used by law enforcers to use the provision in the case of trading in influence. With so many cases of influence trade in Indonesia, the government and the House of Representatives have made changes and refinements to the current corruption eradication laws.

\section{REFERENCE}

[1] Case Lutfi Hasan Ishak v PP, No. 38 / PID.SUS / TPK / 2013 / PN.JKT.PST , see https://putusan.mahkamahagung.go.id/putusan/0f95cf2 
6b00dc5935b66f437d2c4f214 accessed [22 Agustus 2017]

[2] Adami Chazawi, Hukum Pidana Formil \& Materiil KORUPSI di Indonesia, Penerbit Bayumedia Publishing, Malang. (Cetakan VI). 2014.

[3] Bagir Manan (Bekas Ketua Mahkamah Agung), "Vonis Lutfi Hasan Ishaq, hakim Tidak Akurat" dalam http://www.hukumonline.com/berita/baca/lt5380ced29 0a24/mantan-ketua-ma-kritik-vonis-luthfi-hasan [22 Juli 2017]

[4] Policy Paper, Kajian Implementasi Aturan Trading in Influence, Indonesia Corruption Watch, Jakarta. 2014.
[5] Aziz Syamsuddin, 2011, Tindak Pidana Khusus, Sinar Grafika, Jakarta.

[6] Hamzah, Andi, 2006, Pemberantasan Korupsi Melalui Hukum Pidana Nasional dan Internasional, Raja Grafindo Perkasa, Jakarta.

[7] Kostyo, Kennet, 2006, Buku Panduan Mencegah Korupsi Dalam Pengadaan Barang dan Jasa Publik, dalam terjemahan Fahmia Biadib, Jakarta.

[8] Philip, Julia, 2009, The Criminalisation of Trading in Influence in International Anti Corruption Laws, Faculty of Law, University of the Western Cape, South Africa. 